DOI: https://doi.org/10.5565/rev/cli.22 e-ISSN : 2604-5613 Print ISSN: 2605-5893

\title{
Learning to Write in a Second Language: The Role of Guided Interaction in Promoting Children's Noticing from Model Texts
}

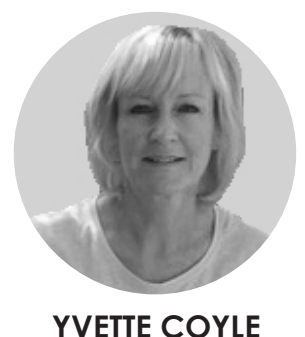

UNIVERSIDAD DE MURCIA

ycoyle@um.es

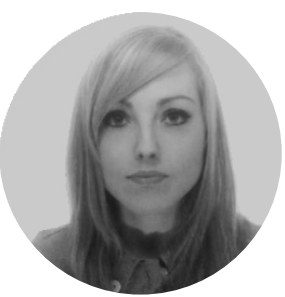

JOSEFA CÁNOVAS GUIRAO

UNIVERSIDAD DE MURCIA

josefa.c.g@um.es
$\mathrm{T}$ his paper illustrates the use of model texts as a written corrective feedback technique with young foreign language learners. The procedure used by the teacher to focus the learners' attention on grammatical, lexical and textual differences between a model story and a draft version written by the children is described, and implications are suggested for the role of feedback processing in promoting $L 2$ learning.

\section{KEYWORDS:}

writen corrective feedback; models; young learners; EFL classroom.

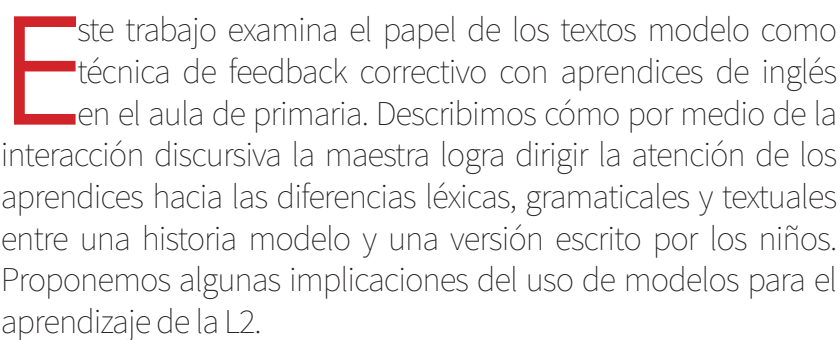

PALABRAS CLAVE:

feedback correctivo; textos modelo; niños; inglés lengua extranjera. 


\section{Introduction}

$\mathrm{n}$ foreign language learning contexts such as Spain, children spend at least twelve years of their lives in primary and secondary education. During this time, they are exposed to English as a subject in the school curriculum for a few hours a week and often with little or no contact with the language beyond the classroom. In many schools, under the guise of a communicative approach to language learning, much of the time is dedicated to explicit focus on forms (FonFs) (Long, 1996) and vocabulary teaching in teacher-dominated classrooms. The development of competence in foreign language (FL) writing is rarely contemplated beyond the completion of textbook exercises. Young learners in mainstream and content classrooms frequently copy, match, underline, circle and fill in gaps in sentences with topic vocabulary, but they are seldom required to write different types of texts in English. As a result, they are denied important opportunities to try out their developing knowledge of the FL and to receive feedback on their writing. Against this backdrop, it seems that many English as a foreign language (EFL) teachers of younger learners in the Spanish educational context are unaware of the instrumental role that writing practice and written corrective feedback (WCF) can play in the linguistic development of their pupils. The idea that engaging in both of these activities might actively contribute to children's foreign language development does not normally form part of current pedagogical agendas. The aim of the present paper is to present and illustrate an instructional approach using model texts as a WCF technique with a group of young EFL learners that led them to engage in collaborative reflection on written narratives with their class teacher, an experience that was found over time to improve the quality of the children's written output.

\section{A rationale for the language learning potential of written corrective feedback}

$\mathrm{T}$ his neglect of writing in young learner classrooms clashes with contemporary theory and research in the field of foreign language writing. The cognitive'writing-to-learn-language' strand of second language acquisition research (Manchón, 2011) highlights the potential of writing to contribute to foreign and second language learning. From this theoretical perspective, it is argued that language learners should be given frequent opportunities to write in the second language (L2) and provided with relevant feedback on their language errors in order to trigger important learning processes including noticing, hypothesis testing and metalinguistic reflection (Ferris, 2010; Williams, 2012). By allowing learners to try out their developing knowledge of the L2 in writing, and by scaffolding this process with corrective feedback, teachers may be able to help learners become more aware of what they know in the L2 and what they do not. From this

"When pairs share
their L2 knowledge when
writing a joint text and
then discuss together the
corrections or differences
they notice between their
own work and the teacher's
feedback, or when teachers
help learners to focus on
errors in their own writing
or on the positive qualities
of model texts, they are
engaging in an important
learning activity.

perspective, raising learners' awareness of 'gaps' in their L2 knowledge can be facilitative of interlanguage development (Schmidt, 2001; Swain, 1985).

Sociocultural theory has similarly advanced our appreciation of the language learning potential of WCF through the importance attached to cognitive development as a socially constructed activity. Inherent to this idea is the Vygotskian premise that the individual appropriation of linguistic knowledge can be co-constructed through collaborative talk during problem-solving tasks. Therefore, when pairs share their L2 knowledge when writing a joint text and then discuss together the corrections or differences they notice between their own work and the teacher's feedback, or when teachers help learners to focus on errors in their own writing or on the positive qualities of model texts, they are engaging in an important learning activity. Seen from both cognitive and sociocultural perspectives, the scaffolding afforded by the pooling of linguistic resources during feedback analysis both in teacher-led whole class discussions or in pair work, would appear to be a useful starting point to promote the creation of new knowledge through a process of what Swain (2006) has referred to as 'languaging' or '...making meaning and shaping knowledge and experience through language' (p98). 
Model texts as a written corrective feedback technique

W ritten corrective feedback can be delivered in a variety of different ways including (a) explicit error correction, (b) use of codes or underlining to signal that an error has been made or (c) the provision of metalinguistic explanations or rules. In recent years alternative techniques including reformulations or model texts have become popular. Both of these more discursive types of feedback consist of providing learners with whole texts rather than lists of errors or codes. Reformulation involves rewriting the learners' text but correcting any grammatical, lexical, spelling or stylistic mistakes while maintaining the original ideas. Models are complete, wellwritten texts created by teachers taking into consideration the content and the genre of the target text, as well as learners' age, proficiency level, etc., but without specifically referring to the learners' written output. Models provide learners with rich sets of appropriate L2 words and structures for a given context, which can help them both identify their own errors and become aware of the alternative ideas and content in the model. They are also a less time-consuming feedback technique for teachers than individual corrections or reformulations, as one or two models can be used in a given class and tailored to meet the proficiency levels of the children.

Studies of model texts with young learners (Cánovas, Roca de Larios \& Coyle, 2015) have found them to be useful in allowing the children not only to identify their own errors, but also to incorporate new lexis and chunks of language and improve the overall structure of their writing. However, since working with models requires further analysis and reflection than when errors are explicitly highlighted by the teacher, researchers have also suggested a useful role for instruction in helping learners take advantage of models. In some classrooms, especially with older learners, a focus on form and writing activities are often the norm and learners are well accustomed to receiving and analysing feedback.

${ }^{66}$ Models are complete, well-written texts created by teachers taking into consideration the content and the genre of the target text, as well as learners' age, proficiency level, etc., but without specifically referring to the learners' written output."

\author{
${ }^{66}$ Models provide \\ learners with rich sets \\ of appropriate L 2 words \\ and structures for a given \\ context, which can help \\ them both identify their \\ own errors and become \\ aware of the alternative \\ ideas and content in the \\ model."
}

However, in young learner classrooms, writing tasks and the provision of feedback are often overlooked in favour of oral communication tasks. This means that children are not only unfamiliar with writing regularly in the L2, but also that they have very little experience of handling feedback on their texts. Consequently, teaching aimed specifically at helping learners to identify and understand the nature of errors in their written output would seem to be a worthwhile venture. This was what we set out to explore.

\section{Multi-stage Writing and Written Corrective Feedback Tasks}

T he experience we describe below took place in a small state school in a village in southeast Spain as part of a larger study on feedback processing. Sixteen children forming a total of eight pairs from two EFL classes in primary education, a grade 4 (aged 9-10 years old) and a grade 5 (aged 10-11 years old) took part in the research. The two EFL classes were divided into a teaching group (grade 5) and the non-teaching group (grade 4), since despite the age difference, the children in both classes had overall similarly low levels of L2 competence.Over the school year, the children took part in two multi-stage writing and feedback tasks. At Stage 1 (Composing stage), the children were asked to jointly write a story in response to a picture prompt. At Stage 2 (Comparison stage), two days later, the pairs were provided with the stories they had written and a model text written by their teacher and discussed or made a note of any differences they could find. At Stage 3 (Rewriting stage), one week after having completed the initial writing task, the children were given the pictures again and asked to rewrite their stories. Between each task and over a period of six weeks, the children in the teaching group devoted one weekly English lesson to writing stories and discussing model versions with their class teacher while the nonteaching group continued with their regular EFL lessons. The procedure followed will be described and illustrated below. 


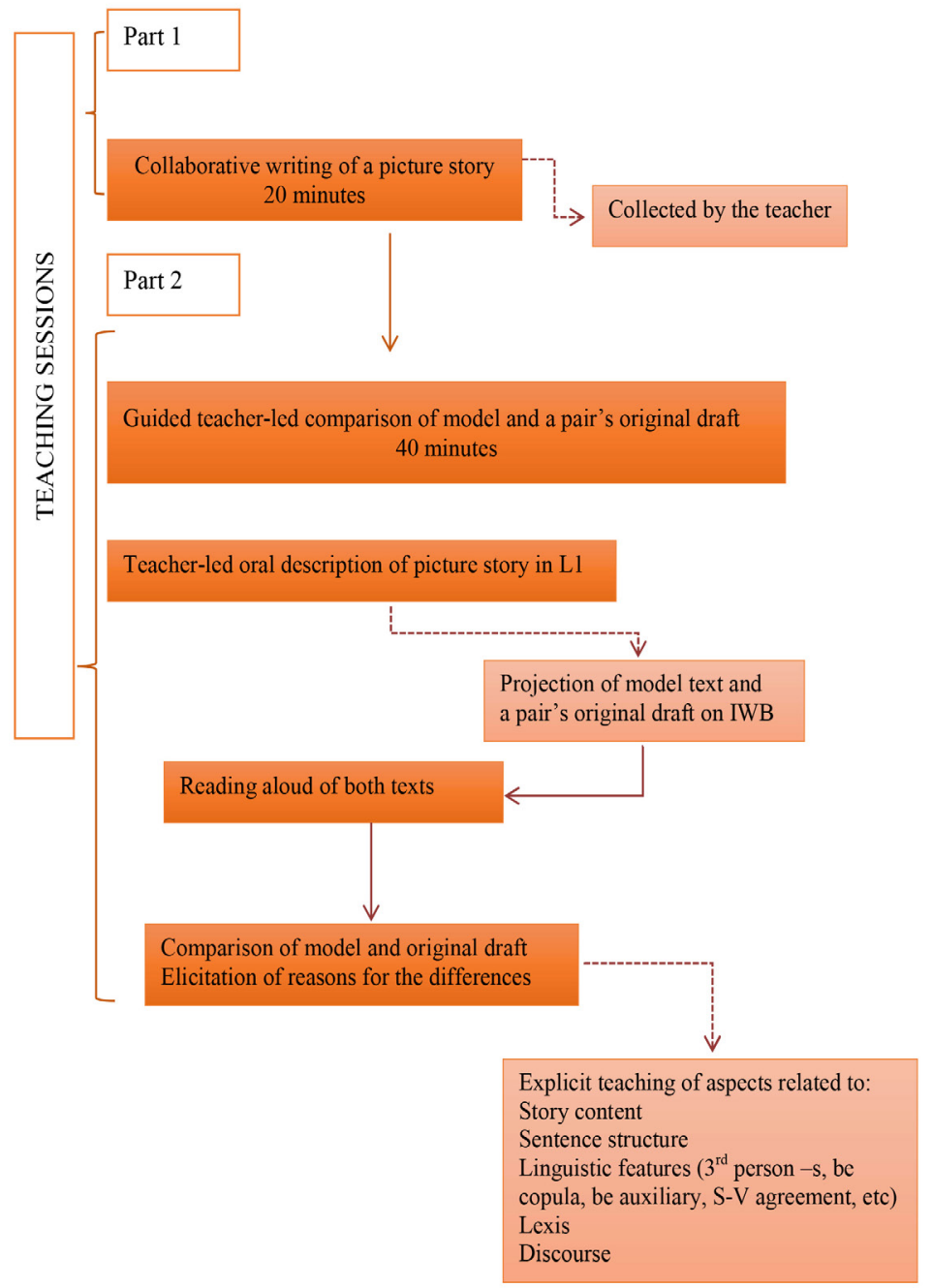

Figure 1.

Structure of the teaching sessions

\section{Teaching children with model texts}

$\mathrm{T}$ he six teaching lessons in which the children worked with model texts were divided into two parts. In every session, firstly the children jointly wrote a story using a set of pictures (Appendix A) to guide their narratives (20 min) and then participated in a whole class discussion activity in which the teacher helped them to identify differences between a model text (Appendix B) and one of their anonymous drafts (40 $\mathrm{min}$ ) (see Figure 1). To begin with, after the children's drafts were collected, the learners were encouraged by the teacher to tell the story in Spanish so that the meaning of the drawings could be clarified collectively. During this discussion, the teacher used mainly English while the children relied mostly on their L1.

\section{Excerpt 1}

Clarifying the meaning

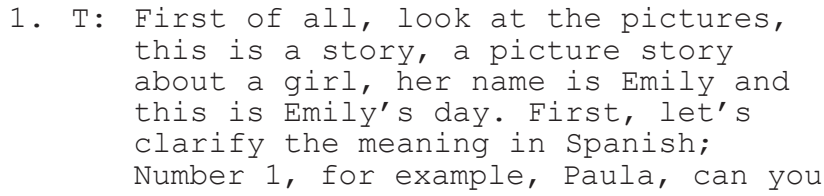

tell me what is happening in number 1? in Spanish first.

2. P1:Vale, Emily termina el colegio...

3. T: Yes, Emily termina el colegio....¿Y qué hora es?

4. P1: Las cinco y cuarto.

5. T: ¿Y qué día es?

6. P1: El uno de mayo.

7. T: Muy bien, Paula seguimos con la viñeta número 2.

8. P2: Emily está en clase de piscina.

9. T: Sí, va a natación...

10. P2: A las cinco y media.

The teacher then projected a model version on the blackboard and wrote alongside it one pair's original text (each week a different pair was chosen) without revealing the identity of the writers. The children were told that the two versions of the stories had been written by Spanish and English children respectively (Picture 1). 


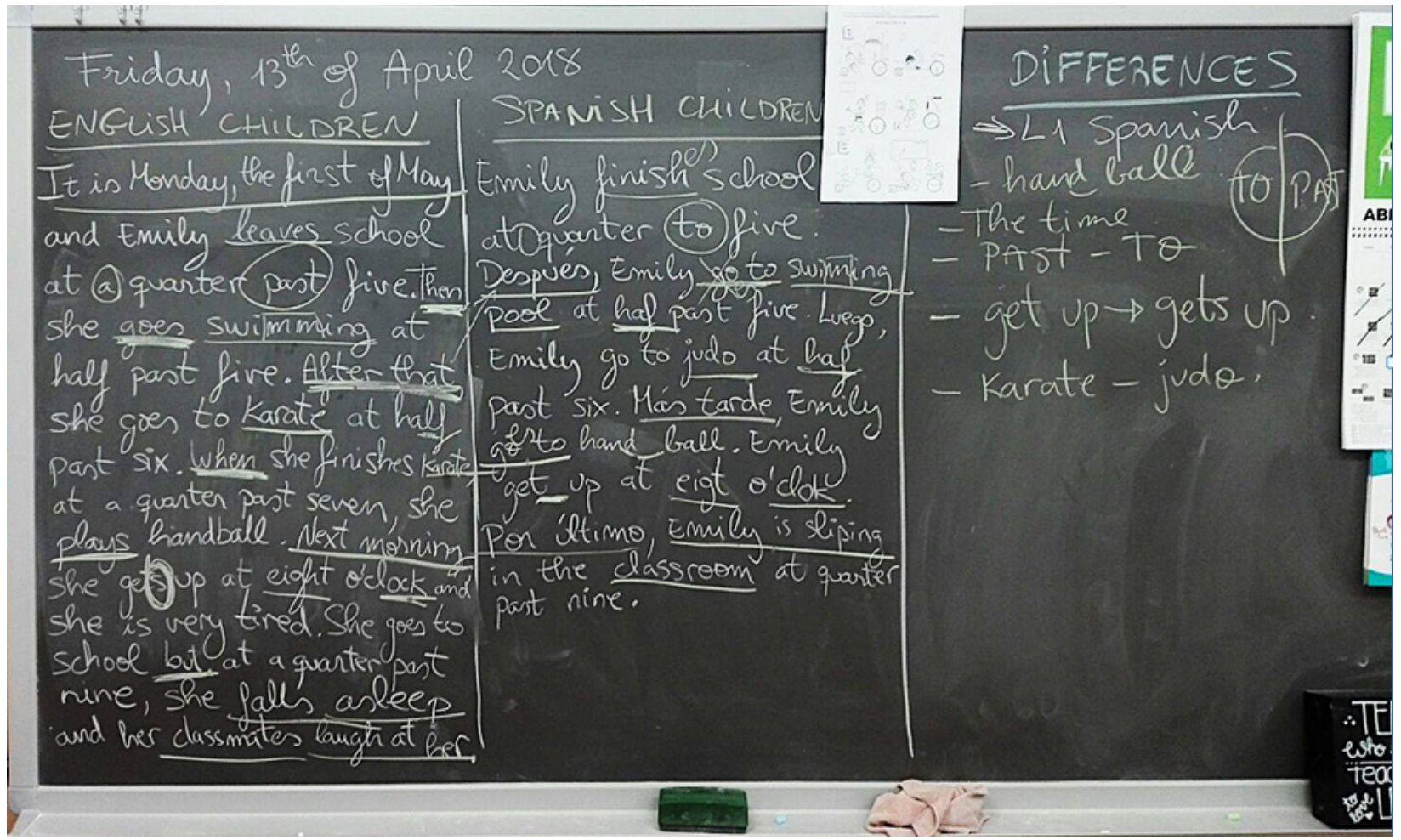

Picture 1. The model version of the picture story and one pair's original draft

Excerpt 2

Explaining the task

1. T: Ok. Well that's the story and here we have a story written by some English children and here is another one written by spanish children. As you can see, there are some differences between them.

2. PP: Yes, yes...

3. T: Well that's what we have to do, find all the differences. The story written by the English children is perfect as English is their first language and the Spanish story, since the children are still learning English, has some mistakes. We have to find them. Is that clear?

The teacher then read both texts aloud and the children followed silently before being asked to identify any differences they could find between the model text and the Spanish children's version.
Excerpt 3

Reading the draft

1. T: OK. Now, the Spanish children's text: (reading) "Emily finish school at quarter to five. Y después, Emily go to swiming pool at haf past five. Luego, Emily go to judo at haf past six. Más tarde Emily go to hand ball. Emily get up at eigt o'clok. Por último Emily is sliping in the classroom at quarter past nine".

2. PP: Hay mucha diferencia...si...

Through guided class discussion, the teacher attempted to raise the children's awareness of five broad categories, namely, (1) the story content, (2) sentence structure, (3) grammar (4) vocabulary and spelling, and (5) discourse. Consequently, when the children found a difference between the text and the model version, the teacher underlined it on the blackboard and explained related linguistic or textual issues. The following examples show how the teacher scaffolded the children's noticing from the model through guided interaction, by helping them to identify and reflect on surface differences between both narratives (Picture 2). 


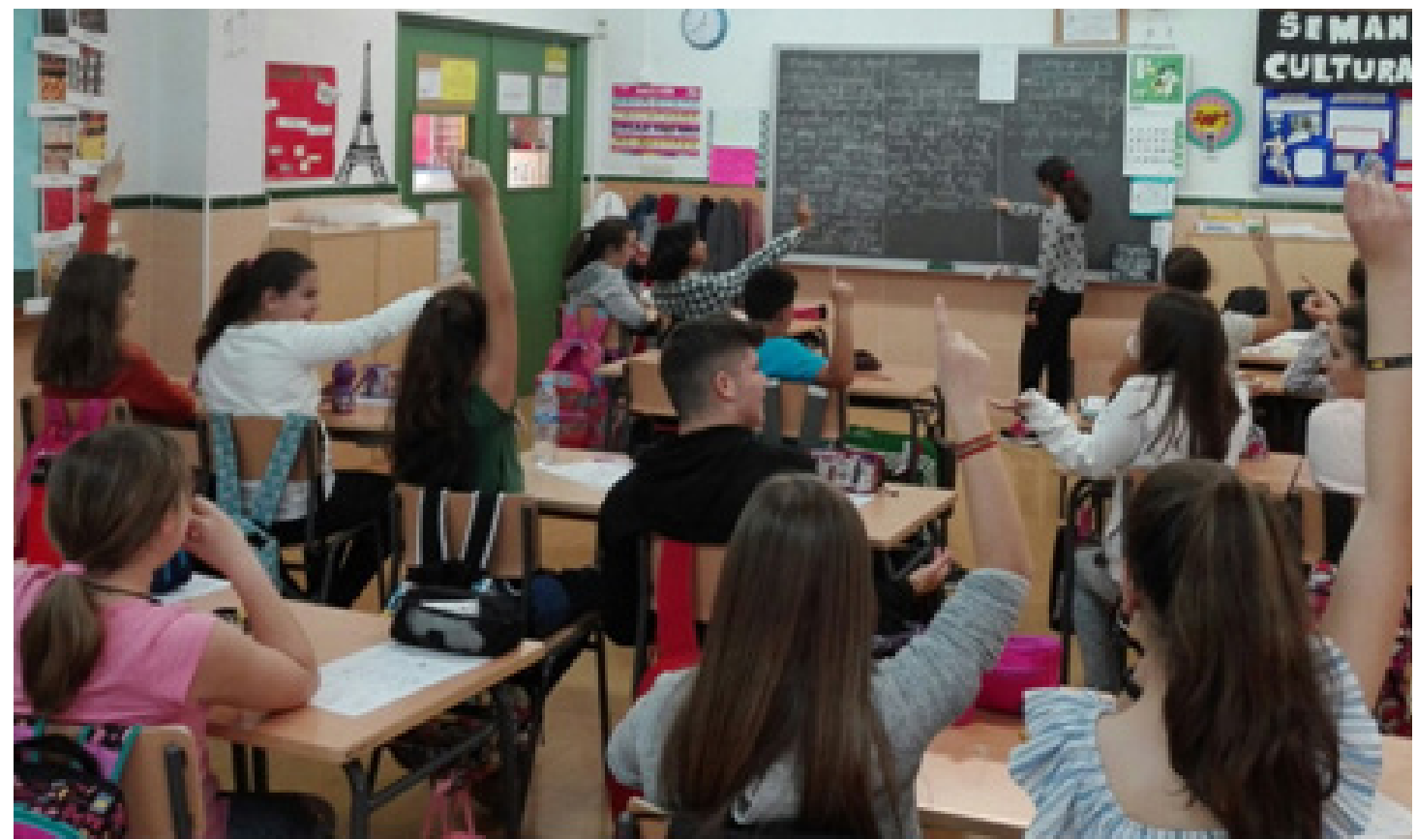

Picture 2. Whole class discussion of the draft and model text

\section{(1) Content}

W hen the children found a content-related difference, the teacher pointed out that the model could be used as a source of ideas to improve their own writing. For example, a common content difference noticed by the children was the spatial location of the story characters in the models. This led the children to make strategic comments on their future writing such as 'Next time, we should include the place'. In the following example, a child noticed that this particular model provided more detailed reference to the temporal setting of the story than the learners' draft, which began by describing the sequence of events.

\section{Excerpt 4}

Noticing differences in story content

1. P1: En la parte de los ingleses especifican un poco más las cosas que las de los españoles, por ejemplo: al empezar la historia dicen "It is Monday the first of May" y los otros escriben "Emily leaves school".

2. T: Supergood! More information. They begin the story by giving more information, ok? They are much more precise. They write the date and the month. So, can you see how they start off situating the story in time. Vey good.

3. P1: Y en el de los Spanish children solamente dicen la situación.

4. T: Very good. Exactly. They only say what Emily is doing. Good difference.

\section{(2) Sentence structure}

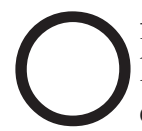
ften, the learners noticed that the models contained longer sentences than the original stories, which enabled the teacher to explain that longer and more complex sentences could be produced by using connectors such as 'when' or 'but'. In Excerpt 5, the teacher explicitly draws the children's attention to the combination in the model of two ideas into a single sentence and encourages them to attempt this in their own writing.

\section{Excerpt 5}

Noticing connectors

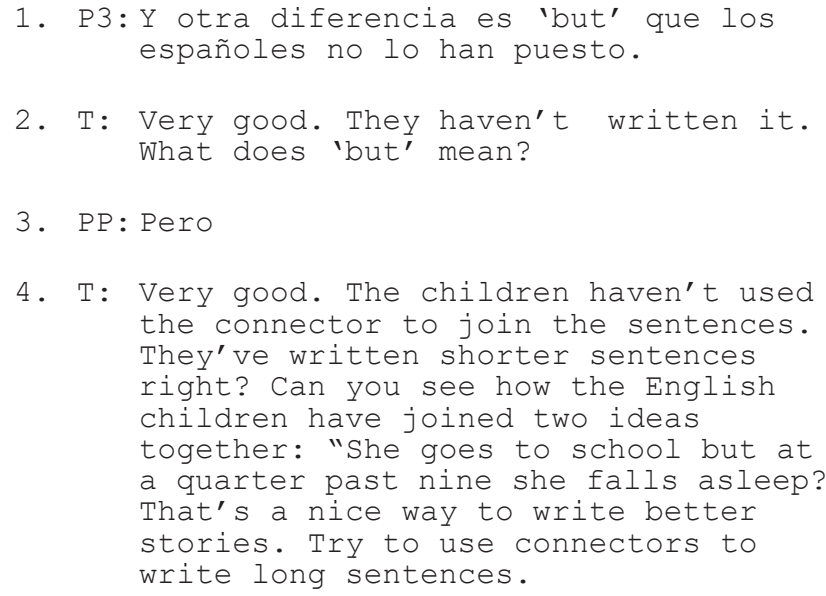




\section{(3) Grammar}

W ithin this category, the learners often noticed that the original texts lacked the third person $-\mathrm{s}$ in verb forms. However, they were generally unable to explain the linguistic rule underlying the difference. As a result, the teacher spent time in every session explaining relevant grammar rules such us the $3^{\text {rd }}$ person singular of the present simple, the be copula, be auxiliary or subject-verb agreement using examples from the children's writing and the model texts. This attempt at assisting learners to make form-meaning connections during input processing is one of the salient characteristics of processing instruction, as attested by Van Patten (2004), and is believed to impact on their developing knowledge of the second language.

\section{Excerpt 6}

Guiding metalinguistic awareness of language form
1. T: What is the difference between 'She goes' and 'Emily go'? Can you explain it? Think

2. P4: Que goes es el pasado...

3. T: Goes is in the past?

4. PP: No, no...

5. T: But you're thinking along the right lines. It's a grammatical difference. 'Goes' is present tense but...

6. PP: La ese! 7. T: The letter ' $\mathrm{s}$ ' good. And what does
this ' $\mathrm{S}$ ' mean?

8. P5: De he o she...

9. T: Exactly! The third person ' $S$ '. We know that the third person of the present singular, I mean when we talk about 'he' or 'she' in the present we have to add the ' $s$ ' to the verb, right?

10. PP: Sí, sí.

11. T: So in the story it's wrong. We don't say 'Emily go', we say'Emily goes'

12.

13. P5: También se les ha olvidado ponerle la ese de tercera persona in she get...

14. T: Yes, perfect! Super important difference! It should be...

15. P5: She gets up

\section{(4) Lexis and Spelling}

$\mathrm{T}$ he learners often inquired as to the meaning of lexical items in the models they were exposed to. They also began to notice the L2 forms in the models for L1 words present in the original texts and paid more attention to details of spelling. In the following two examples, learners point out the use of the L1 term 'despues' in the initial text before locating its equivalent in the model 'After that'. Two spelling errors ('haf' and 'cloc') are also highlighted by the children, which prompts a corresponding phonological explanation from the teacher.

\section{Excerpt 7}

Focusing on L1-L2 matches

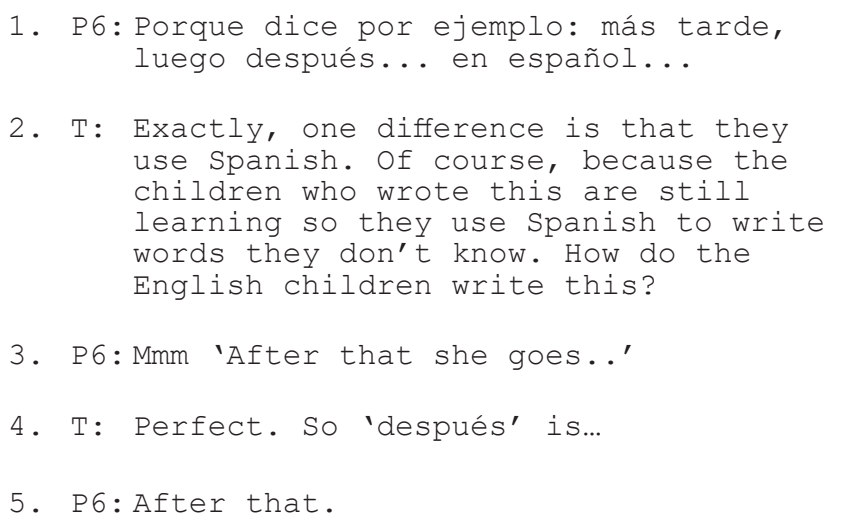

Excerpt 8

Noticing spelling

1. P7: Que pone haf en vez de half.

2. T: Very good. They have missed a letter. We don't pronounce the L but we write half. It's a spelling difference. Next Triana.

3. P8: Que en o'clok le falta la c.

4. T: Another spelling difference very good!

\section{(5) Discourse}

W hen children identified discourse markers such as 'finally' in the model texts, the teacher spent time highlighting textual differences such as story structure (beginning, middle and ending) and the use of story-writing terminology (Once upon a time, one day, first, after that, then, next, and finally) as a way of helping the children to improve their narrative texts. When this process was repeated several times, the children were able to differentiate clearly the three parts in the story and tried subsequently to include them in their own texts. 


\section{Pedagogical Implications}

$\mathrm{T}$ he teacher's interventions in drawing the children's attention to linguistic and textual differences in the imperfectly written texts of their peers in comparison to model texts proved valuable in helping them to make better use of the feedback. In the second multi-stage task, the pairs in the teaching group made fewer errors and wrote qualitatively better texts that the learners who had not been helped to analyse models (Table 1).

The question is, then, what was it that enabled the children in the teaching group to produce better texts? The answer, we believe, lies in the social dynamics of the classroom discourse, which became a forum for teacher-led collective 'languaging'. As described above, the children were shown how to go about analysing diverse features of the model text while simultaneously supported in the development of metalinguistic knowledge through a process of dialogic interaction with the teacher. The teacher's role in scaffolding the children's noticing and in offering metalinguistic explanations for errors in the sample texts over a sustained six-week period seemed to have raised the children's awareness of form-function mappings and strengthened their grammatical, lexical and discursive knowledge, thus priming them to become more perceptive when handling feedback on their writing.

The findings of our study suggest a role in the classroom for consciousness-raising activities using model texts to

Table 1. Sample stories written after the instructional intervention

\section{Teaching Group}

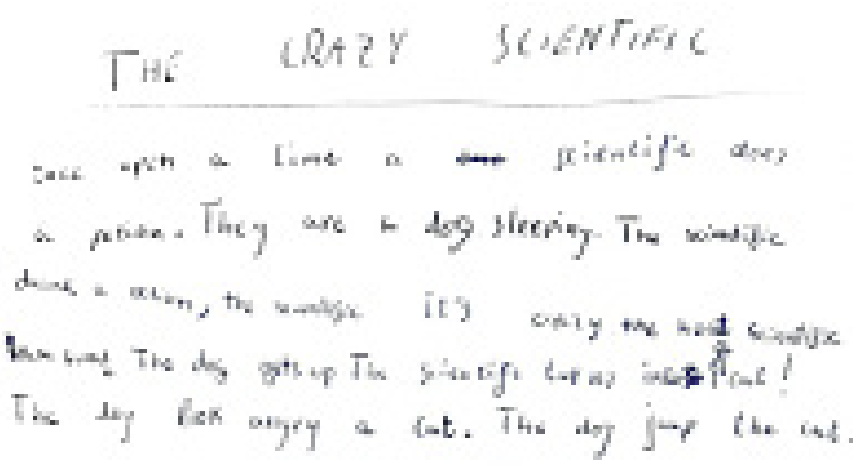

\section{The Crazy Scientific}

Once upon a time a one scientific does a potion. They are a dog sleeping. The scientific drink a potion, the scientific it's crazy. The head scientific bumm, bumm! The dog gets up. The scientific turns into a cat! The dog looks angry a cat. The dog jump the cat.

\section{${ }^{66}$ The question is, then, what was it that enabled the children in the teaching group to produce better texts? The answer, we believe, lies in the social dynamics of the classroom discourse, which became a forum for teacher-led collective "languaging,"}

help younger, less proficient learners improve their foreign language writing and develop their meta awareness of language as a system. Without the experience and knowledge accumulated in the teaching sessions, children in the nonteaching group struggled to notice and understand linguistic features in the input. However, by actively directing learners' noticing and filling in gaps in their L2 knowledge, the teacher helped the children in the teaching group to improve the quality of their noticing from the model and improve their written output. It seems important, therefore,

\section{Non-teaching group}

$$
\begin{aligned}
& \text { The cinliye and do }
\end{aligned}
$$

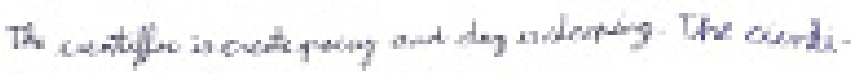

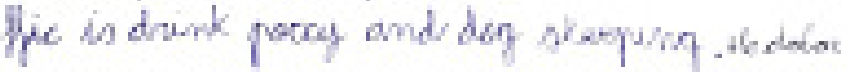

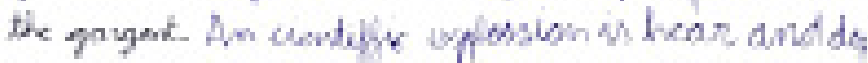

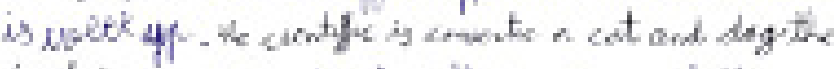

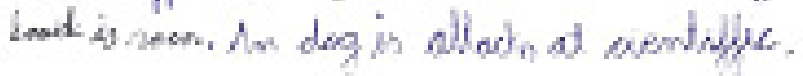

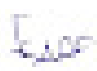

$$
\text { The then }
$$

The cientiffic and dog

The cientiffic is create poccy and $\operatorname{dog}$ is sleeping. The cientiffic is drink poccy and dog sleeping. He dolor the gargant. An cientiffic explossion is hear and dog is week up. He cientiffic is convertic a cat and dog the look is roon. An dog is attacks at cientiffic. The end. 
for teachers and future teachers to become more aware of the benefits to be gained from regular writing practice and guided feedback processing, as well as of the theoretical implications involved in the impact of writing on children's second language development (Manchón, 2011).

Further practical considerations concerning the nature of feedback, the pairing of learners and the integration of reading and writing activities deserve special attention. Models are not a personalized form of feedback directed at individual errors in children's writing. Therefore, for younger learners at different proficiency levels, the uniformity of model texts as a 'one size fits all' technique may not always be the most appropriate solution. The idea of preparing two or three models to cater for the different proficiency levels within EFL classes might be a worthwhile option to explore. In practice, this would mean elaborating various models at different levels of difficulty to match the diversity that characterizes mixed-ability classrooms in primary education. Teachers might also alternate models with other forms of WCF, including error correction, reformulation or metalinguistic explanations, which might make specific errors more perceptually salient. Becoming aware of the advantages afforded by different types of feedback and selecting suitable techniques for different language learning purposes should be a central part of the teaching agenda of EFL teachers and trainees.

It is also true that some thought should be given to assigning learners in pairs. Placing two children together does not necessarily guarantee that they will collaborate effectively. The children in this study worked well together, although lower proficiency learners had greater difficulties in providing support for each other given their own limited knowledge of the L2. In this respect, the idea of 'paired writing' (Yarrow \& Topping, 2001), in which more experienced and knowledgeable learners actively assist less proficient peers in producing a collaborative text using a

${ }^{66}$ The findings of our study suggest a role in the classroom for consciousness-raising activities using model texts to help younger, less proficient learners improve their foreign language writing and develop their meta awareness of language as a system. structured training programme might be profitably extended to EFL classes and activities involving WCF.

Writing and related feedback activities would also profit from being integrated with reading tasks so that children develop skills in comprehension, word recognition, spelling, morphology and text structure, by first reading and then writing related texts in connection to other curriculum subjects they might be studying in English (Rose \& Martin, 2012). In this way, models could be used with specific texttypes including narratives, reports, instructions, explanations, etc. This might be equally useful in CLIL classrooms where learners are often required to produce written accounts of experiments or other scientific phenomenon. Bilingual dictionaries might also be a useful tool for younger learners, as they enable children to bridge gaps in their L2 knowledge by using their L1 knowledge as a referent. Finally, the use of written computer-mediated communication (CMC) might be used to increase learners' motivation to write. Using technology, children can begin to communicate with speakers of other languages and to participate in interactional exchanges even in foreign language learning contexts. In conclusion, if teachers understand more fully how writing and feedback processing can contribute to second language learning, they are more likely to integrate these tasks into their classroom practice.

\section{References}

Cánovas Guirao, J., Roca de Larios, J. \& Coyle, Y. (2015). The use of models as a written feedback technique with young EFL learners. System 52 (1), 63-77.

Ferris, D. (2010). Second language writing research and written corrective feedback in SLA. Intersections and practical applications. Studies in Second Language Acquisition, 32, 181-201.

Long, M. H. (1996). The role of the linguistic environment in second language acquisition. In W. Ritchie \& T. Bhatia (Eds.), Handbook of second language acquisition (pp. 413-468). San Diego, CA: Academic Press.

Manchón, R. M. (2011). Writing to learn the language: Issues in theory and research. In R. M. Manchón (Ed.), Learning to write and writing to learn in an additional language (pp. 61- 82). Amsterdam: John Benjamins.

Rose, D. \& Martin. J.R. (2012).Learning to Write/Reading to Learn: Genre, Knowledge and Pedagogy in the Sydney School: Scaffolding Democracy in Literacy Classrooms. Sheffield, UK: Equinox Textbooks \& Surveys in Linguistics.

Schmidt, R. (2001). Attention. In P. Robinson (Ed.), Cognition and second language instruction (pp. 3 - 32). Cambridge: Cambridge University Press.

Swain, M. (1985). Communicative competence: Some roles 
of comprehensible input and comprehensible output in its development. In S. Gass \& C. Madden (Eds.), Input in second language acquisition (pp. 235-253). Rowley, MA: Newbury House.

Swain, M. (2006). Languaging, agency and collaboration in advanced second language learning. In H. Byrnes (Ed.), Advanced language learning: The contributions of Halliday and Vygotsky (pp. 95-108). London, UK: Continuum.

VanPatten, B. (2004). Input processing in SLA. In B. VanPatten (Ed.), Processing instruction: Theory, research and commentary (pp. 5-32). Mahwah, NJ: Erlbaum.

Williams, J. (2012). The potential role(s) of writing in second language development. Journal of Second Language Writing, 21, 321 - 331.

Yarrow, F., \& Topping, K. J. (2001). Collaborative writing: The effects of metacognitive prompting and structured peer interaction. British Journal of Educational Psychology, 71, $261-282$.

\section{Appendix B}

Model text

It is Monday, the first of May and Emily leaves school at a quarter past five. Then, she goes swimming at half past five. After that, she goes to karate at half past six. When she finishes karate, at a quarter past seven, she plays handball. Next morning, she gets up at eight o'clock and she is very tired. She goes to school but at a quarter past nine, she falls asleep and her classmates laugh at her.

Reprinted from System Vol 52. J. Cánovas Guirao, J. Roca de Larios \& Y. Coyle. The use of models as written feedback technique with young EFL learners. p75 Copyright (2015), with permission from Elsevier.

\section{Appendix}

Appendix A

The Picture Story Prompt

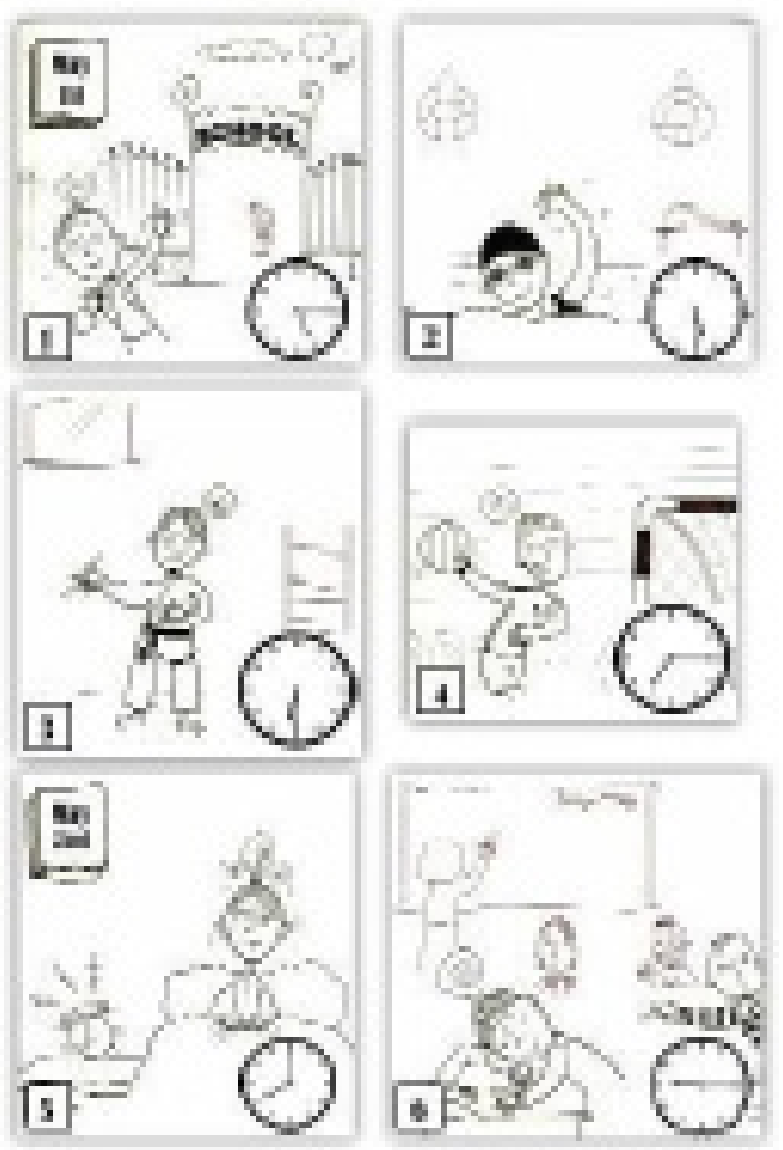

